\title{
Epidemiological and Clinical Characteristics and Risk Factors for Mortality of Inpatients with COVID- 19 in Golestan Province, Iran: A Retrospective Cohort Study
}

\section{Mohammad Reza Honarvar}

Golestan University of Medical Sciences and Health Services

\section{Gholamreza Roshandel}

Golestan University of Medical Sciences and Health Services

Hesamaddin Shirzad-Aski

Golestan University of Medical Sciences and Health Services

Alijan Tabarraei

Golestan University of Medical Sciences and Health Services

Alireza Tahamtan

Golestan University of Medical Sciences and Health Services

Mousa Ghelichi-Ghojogh

Shiraz University of Medical Sciences

\section{Abdolreza Fazel}

Golestan University of Medical Sciences and Health Services

\section{Serajeddin Arefnia}

Golestan University of Medical Sciences and Health Services

Nahid Jafari

Golestan University of Medical Sciences and Health Services

Mohsen Mansoury

Golestan University of Medical Sciences and Health Services

Abdolhalim Rajabi ( $\sim$ rajabiepid@gmail.com )

Golestan University of Medical Sciences and Health Services https://orcid.org/0000-0002-0698-8166

\section{Research}

Keywords: COVID-19, Acute Respiratory Distress Syndrome, Death, Iran

Posted Date: September 28th, 2020

DOI: https://doi.org/10.21203/rs.3.rs-80960/v1 
License: (c) (i) This work is licensed under a Creative Commons Attribution 4.0 International License. Read Full License 


\section{Abstract}

Background: Coronavirus disease 2019 (COVID-19) is an emerging infectious disease that was first reported in Wuhan, China, and has subsequently spread worldwide. We aimed to further clarify the epidemiological and clinical characteristics of 2019-nCoV pneumonia and risk factors associated for mortality.

Methods: In this retrospective cohort study, we included inpatient with acute respiratory distress syndrome at Golestan University of Medical Sciences Hospitals (Golestan province, Iran) who had been discharged or had died in 2020. Epidemiological, clinical, and laboratory data, including samples for viral RNA detection, were extracted from electronic medical records and compared between recovered and died cases. We used multiple logistic regression methods to explore the risk factors associated with inhospital death.

Results: In overall 2,835 acute respiratory distress syndrome patients were included in this study, of these patients, 874 (30.83.9\%) were positive for $2019 \mathrm{nCoV}$, and 1,046 (36.90\%) were negative and 915 (32.28\%) were not available for PCR result. Five hundred and sixty-three patients $(19.86 \%)$ died, 1,687 patients (59.51\%) were recovered, and $585(20.63 \%)$ under treatment. Of the total deaths, only $288(10.15 \%)$ were attributed to COVID-19. The most common symptoms at onset of illness were respiratory distress $(1,795$ [63.32\%]), fever (1,601 [56.47\%]), dry cough (1,595 [56.26\%]), Sore throat (445 [15.70\%]), and myalgia (342 [12.06\%]).One thousand and twelve (35.7\%) had 1 or more coexisting medical conditions. In multiple logistic regression analysis, risk factors associated with the death included older age (OR (Odds Ratio), 1.03; 95\% Cl; 1.02-1.04), blood oxygen level (SpO2<93\%) (OR, 2.44; 95\% Cl; 1.79-3.31), comorbidities (OR, $2.15 ; 95 \% \mathrm{Cl} ; 1.62-2.84)$, respiratory distress (OR, $1.74 ; 95 \% \mathrm{Cl} ; 1.28-2.37)$, and headache (OR, $0.4495 \% \mathrm{Cl}$; $0.21-0.92)$.

Conclusions: The 2019-nCoV infection caused collections of severe respiratory illness and was associated high ratio of hospitalization in ICU and high mortality. Older age and comorbidities were associated with more risk of death among patients with 2019nCoV.

\section{Background}

In December 2019, a number of cases of pneumonia by unknown origin were identified in Wuhan, the capital city of Hubei province, China (1). Clinical evidence showed that these cases were very similar to viral pneumonia (1-5). Most patients reported that worked or lived in the seafood market, and live wild animal. In the early stages of the pneumonia, severe acute symptoms of respiratory infection occurred, with some patients rapidly developing acute respiratory distress syndrome (ARDS), acute respiratory failure, and other serious complications. On January 7, a new coronavirus was detected by the Chinese Centers for Disease Control and Prevention, which was subsequently named by the World Health Organization as the new Coronavirus 2019 (nCoV-2019) (4, 6). Emergence of 2019-nCoV has attracted global attention, and WHO has declared the COVID-19 a public health emergency of international concern 
(PHEIC) $(7,8)$. Since the outbreak of Acute Respiratory Syndrome (SARS) in Guangdong, China, in 2003, WHO has announced five PHEIC cases: H1N1 (2009, polio (2014), Ebola in West Africa (2014), Zika (2016) and Ebola in the Democratic Republic of the Congo (2019) (9). Announcing a PHEIC is an immediate call at the highest level for the international community to launch a global concerted effort to stop the spread of the disease, which requires serious public health activities, high-level political commitment and a sufficient budget (7).Common symptoms of this infection include respiratory symptoms, fever, cough, and respiratory distress. In more severe cases, the infection can cause pneumonia, severe acute respiratory syndrome, kidney failure, and even death (2).

According to the latest World Health Organization report, since the announcement of the first case of Covid-19, 4,248,389 cases and 294,046 deaths due to the disease have been reported in more than 180 countries. So that More than 80 percent of deaths in the United States and Europe, as well as 37 and 55.5 percent of deaths, were reported in the United States and Europe, respectively. In Iran, 112,725 cases of patients and 6,783 deaths have been reported (10). Due to the fact that the disease has spread to all countries of the world, including Iran, this study was conducted to determined Epidemiological and clinical characteristics and risk factors for mortality of inpatients with COVID-19 in Golestan province, Iran.

\section{Methods}

This is a retrospective cohort study of 2,835 patients acute respiratory distress syndrome aged $<1$ to 99 years hospitalized at Golestan university of Medical Sciences Hospitals in Golestan provinces, Iran. The study was approved by the Research Ethics Commission of Golestan University of Medical Sciences (IR.GOUMS.REC.1398.385). The patients with acute respiratory distress syndrome admitted to Hospitals of Golestan university of Medical Sciences in 2020, were enrolled. We obtained the medical records and compiled data for hospitalized patients with laboratory-confirmed Covid-19. A confirmed case of Covid-19 was defined as a positive result on real-time reverse-transcriptase-polymerase-chain-reaction (RT-PCR) assay of nasal and pharyngeal swab specimens and suspected cases of 2019nCoV or Acute Respiratory Distress Syndrome was defined the negative test of PCR and hospitalized. We obtained epidemiological, demographic, clinical, laboratory, management, and outcome data from patients' medical records. The primary end point was admission to an intensive care unit (ICU), or the use of mechanical ventilation. Secondary end point was the death of the composite end point.

Descriptive analyses of the variables were expressed as median (interquartile range [IQR]), or number (\%) or simple ranges, as appropriate. No imputation was made for missing data. Means for continuous variables were compared using independent group $\mathrm{t}$ tests when the data were normally distributed; otherwise, the Mann-Whitney test was used. Proportions for categorical variables were compared using the $\chi 2$ test, although the Fisher exact test was used when the data were limited. All epidemiological, demographic, clinical exposures were tested for association with end point in univariate analysis and those with $\mathrm{P}<0.20$ were then entered into a logistic regression model to examine their independent effect. 
All statistical analyses were performed using STATA 12.0 software (Stata Corporation, College Station, TX, USA).

\section{Results}

In overall, 2,835 hospitalized patients with suspected $2019 \mathrm{nCoV}$ nasal and pharyngeal swab specimens were prepared and send to the laboratory for PCR. Of these patients, $874(30.83 .9 \%)$ were positive for $2019 \mathrm{nCoV}$, and 1,046 (36.90\%) were negative and 915 (32.28\%) were not available for PCR result (Table 1).

The demographic and clinical characteristics of the patients are shown in Table 1. The median age was 54 years (IQR, 41-67; range, 0-99 years), and 1,635 (57.67\%) were men. The median durations from first symptoms to hospital admission, and death were 2 days (IQR, $0-3$ ), and 7 days (IQR, 4-13), respectively. Among them, there were 32 patients with exposure history of COVID-19 (Table 1). Of these patients, $17.92 \%$ were ventilated, $14.50 \%$ had SPo2 less than $93 \%$, and $11.99 \%$ were admitted to the ICU.

Of the 2,835 patients, $1012(35.7 \%)$ had 1 or more coexisting medical conditions. cardiovascular disease (486 [17.14\%]), diabetes (423 [14.92\%]), Chronic lung disease (177 [6.24\%]) and Hypertension (77 [2.72\%]) were the most common coexisting conditions (Table 1).

The most common symptoms at onset of illness were respiratory distress $(1,795$ [63.32\%]), fever (1,601 [56.47\%]), dry cough (1,595[56.26\%]), Sore throat (445 [15.70\%]), and myalgia (342 [12.06\%]). Less common symptoms were headache, fatigue, abdominal pain, chest pain, diarrhea, nausea, and vomiting (Table 1).

A secondary end-point (death) event occurred in 563 patients (19.86\%), that 1,687 patients $(59.51 \%)$ were recovered, and 585 (20.63\%) under treatment. However, of the total deaths, only 288 deaths were confirmed by the Golestan University of Medical Sciences Death Committee for COVID-19 (Table 1). Thus, the mortality rate for this date was $10 \%$ for COVID-19.

Table 2 demonstrates that when compared with death and recovered cases, the death cases were older $(P<.001)$ and most of them were men $(54.53 \% ; p=0.03)$. More death cases presented with initial symptoms of respiratory distress compared with those recovered $(77.08 \%$ versus $59.63 \% ; P<.001)$ and lower if blood oxygen level (SpO2<93\%) (33.68\% versus 12.27\%; $p<0.001)$. Compared with recovered cases, death cases had a higher proportion of comorbidities, including cardiovascular disease $(27.78 \%$ versus 13.22$)$, diabetes $(23.61 \%$ versus $12.98 \% ; P<0.001)$, chronic lung disease $(11.81 \%$ versus $4.68 \% ; P$ $<0.001)$, Chronic kidney disease $(7.64 \%$ versus $2.37 \% ; P<0.001)$ and cancer $(3.47 \%$ versus $0.95 \% ; P=$ $0.001)$.

Multiple logistic regression models showed that several factors were associated with death in confirmed cases of $2019 \mathrm{nCoV}$, which included age of patents (OR $=1.03,95 \% \mathrm{Cl}: 1.02-1.04)$, blood oxygen level $(\mathrm{SpO} 2<93 \%)(\mathrm{OR}=2.44,95 \% \mathrm{Cl}: 1.79-3.31)$, comorbidities $(\mathrm{OR}=2.1595 \% \mathrm{Cl}: 1.62-2.84)$, respiratory 
distress $(\mathrm{OR}=1.74,95 \% \mathrm{Cl}: 1.28-2.37)$ and headache. Although most of the variables mentioned were associated with higher likelihood of death, but headache was negatively associated with death $(\mathrm{OR}, 0.31$; 95\% Cl, 0.13-0.70) (Table 3).

\section{Discussion}

During this study, the clinical status of patients admitted to hospitals of Golestan province including the common symptoms of COVID-19 patients and their companions, as well as the clinical outcomes and characteristics of patients were evaluated. In addition, this study reviewed the influencing factors of fatality as a retrospective cohort study. As of April 20, 2020, 2835 cases of suspect COVID-19 were hospitalized, of which about $31 \%$ were reported to be a definite case of COVID-19. Circa $12 \%$ of the patients had to be admitted to the ICU, and about $20 \%$ of the patients expired, of these proportions, only $51 \%$ tested positive for COVID-19. Therefore, fatality rate for COVID-19 about $10 \%$. Moreover, circa $60 \%$ of the patients were discharged from the hospitals with complete recovery.

Coronavirus is among the basic pathogens of respiratory diseases. SARS-Corona and MERS-Corona virus are the two most robust pathogens that have caused an epidemic in recent years. These two pathogens cause severe respiratory symptoms in patients. These viruses caused the involvement of a huge part of human society in the world (11). However, the new coronavirus has caused a totally different condition all over the world.

The experience of previous viruses had shown that the mortality rate for the SARS virus was more than $10 \%$ and for the MERS was more than $35 \%(12-14)$. However, this value is different for the new coronavirus, in a way that the mortality rate has shown to be $1.5 \%$ in the present study. Nevertheless, it should be noted that future death records should be reported in inpatients.

The most common clinical symptoms of the patients of the trial include shortness of breath, fever, and dry cough. Unlike the present study, the most common finding in Wuhan city of China was fever (in $98 \%$ of patients) (1). A reason for this difference in the clinical signs between the patients in Iran and China is the way of providing services based on the type of patient. In Wuhan, all patients with mild symptoms were kept in hospital or tested for the virus, however, between Iranian patients, only those with severe respiratory symptoms were admitted or PCR-tested. This difference in methods led to the fact that most of the patients included in the present study had severe symptoms of coronavirus including severe shortness of breath. However, in general, the basic presented symptoms in patients were similar to the previous coronavirus diseases, including SARS and MERS $(15,16)$.

During our study, it was shown that the total reported cases of coronavirus in men were higher than women. The same rate of infection incidence was also seen in MERS and SARS. The lower susceptibility of women to the disease may be partly due to the female hormones that give them immunity(17). In addition, circa half of the patients of coronavirus in the present study had at least one underlying disease, which was mainly cardiovascular and diabetes disease. This finding was similar to that of MERS (18). 
Basically, our findings indicate that the disease regularly invades men of elder ages with underlying diseases and suppression of the immune system.

Moreover, the risk factors of deaths due to the coronavirus were investigated in our study. It was shown that the age, $\mathrm{SPO}_{2}$ of less than $93 \%$, having underlying diseases, and the onsets of symptoms with respiratory distress are among the main risk factors or predictors of fatalities due to coronavirus. The findings of the present study are consistent with the results of the study of Wu et al. (19). These findings are also consistent with the results of the study of Wu et al. (19) and Zhou et al. (20). Nonetheless, these findings can be explained by the fact that the PCR test does not have a high sensitivity in detecting coronavirus in COVID-19 patients so that a number of patients with CT scan results showing evidence of severe pulmonary involvement had negative PCR results. On the other hand, during the early and middle periods of the epidemic, there were multiple sampling errors for PCR because of the fear of the healthcare staff from being involved by the virus, as well as not having the proper skill. As a result, these errors led to misclassification of patient. Therefore, it should be noted that expired patients with a negative PCR result were necessarily not free of the Coronavirus infection. This is the reason for the similar death risk factors for both groups. Interestingly, the onset of symptoms with a headache in cases where their PCR test was positive showed an inverse relationship with fatality and reduced chance of death up to $70 \%$. However, it should be noted that obtaining a history for the headache is a subjective concept that may not be recorded accurately in the epidemic situation. Therefore, this finding should be cautiously interpreted and used.

There were a number of limitations in our study that may have affected the results. First, there was a number of missing data in some variables that may have reduced the study's power to assess the effect of that variable on death. This shows that there is a need for a more robust database of patients in Iran(21), and unfortunately, there is a severe weakness. Second, in this study, we were not able to use laboratory data. This was because of the fact that the laboratories data were not accurate enough. Third, we did not have access to the CT scan reports, because the patients' database only included the CT images, not the reports, which were used in the clinical setting. We were also not able to re-examine the whole CT images because of the current emergency situation.

\section{Conclusions}

However, according to the conducted search, this is the first retrospective cohort report in Golestan province. The 2019-nCoV infection caused collections of severe respiratory illness and was associated high ratio of hospitalization in ICU and high mortality. This study generally identified two important factors for fatality including old age and underlying diseases. On that account, we can try to decrease the fatality by planning on care for these groups. Among the underlying diseases, diabetes, as well as cardiac, lung, and kidney diseases play an important role in the fatality of Coronavirus patients.

\section{Abbreviations}


ARDS: Acute Respiratory Distress Syndrome; nCoV-2019: New Coronavirus 2019; PHEIC: Public Health Emergency of International Concern; SARS: Sever Acute Respiratory Syndrome; RT-PCR: ReverseTranscriptase-Polymerase-Chain-Reaction; ICU: Intensive Care Unit; CT: Computerized Tomography.

\section{Declarations}

\section{Ethics approval and consent to participate}

The study was approved by the Research Ethics Commission of Golestan University of Medical Sciences (IR.GOUMS.REC.1398.385).

\section{Consent for publication}

Not applicable.

\section{Authors' contributions}

MRH, GR and AR originated the research idea and analyzed the data. HS, AT, MG and MM designed the study protocol. AT and AT confirmed the samples. AF, SA, and NJ managed the data collection. AR, MRH and GR drafted the manuscript. All authors confirmed that they meet ICMJE criteria for authorship.

\section{Availability of data and material}

The datasets used and/or analyzed during the current study are available from the corresponding author on reasonable request.

\section{Competing interests}

The authors declare that they have no competing interests.

\section{Funding}

No funding available for this study.

\section{Acknowledgements}

The author would like to acknowledge, Specialized Hospital of Golestan University of Medical Sciences for making the data for this research undertaking available. The authors are also grateful to data collectors.

\section{References}

1. Huang C, Wang Y, Li X, Ren L, Zhao J, Hu Y, et al. Clinical features of patients infected with 2019 novel coronavirus in Wuhan, China. 2020;395(10223):497-506. 
2. Wang D, Hu B, Hu C, Zhu F, Liu X, Zhang J, et al. Clinical characteristics of 138 hospitalized patients with 2019 novel coronavirus-infected pneumonia in Wuhan, China. 2020;323(11):1061-9.

3. Li Q, Guan X, Wu P, Wang X, Zhou L, Tong Y, et al. Early transmission dynamics in Wuhan, China, of novel coronavirus-infected pneumonia. 2020.

4. Chen N, Zhou M, Dong X, Qu J, Gong F, Han Y, et al. Epidemiological and clinical characteristics of 99 cases of 2019 novel coronavirus pneumonia in Wuhan, China: a descriptive study. 2020;395(10223):507-13.

5. KALTEH EA, FARAROOEI M, ALJALILI S, GHELICHI-GHOJOGH MJIJOPH. Susceptibility to COVID-19 in Pregnant and Breastfeeding Women. 2020;49:132-3.

6. Organization WH. Clinical management of severe acute respiratory infection when novel coronavirus ( $\mathrm{nCoV}$ ) infection is suspected: interim guidance, 25 January 2020. World Health Organization, 2020.

7. Dong Y, Mo X, Hu Y, Qi X, Jiang F, Jiang Z, et al. Epidemiological characteristics of 2143 pediatric patients with 2019 coronavirus disease in China. 2020.

8. Munn Z, Moola S, Riitano D, Lisy KJljohp, management. The development of a critical appraisal tool for use in systematic reviews addressing questions of prevalence. 2014;3(3):123.

9. Soni AK. Update on the SARS-CoV-2 (COVID-19) Outbreak: A Global Pandemic Challenge. 2020.

10. Perz JF, Armstrong GL, Farrington LA, Hutin YJ, Bell BPJJoh. The contributions of hepatitis $B$ virus and hepatitis $C$ virus infections to cirrhosis and primary liver cancer worldwide. 2006;45(4):529-38.

11. Hu B, Zeng L-P, Yang X-L, Ge X-Y, Zhang W, Li B, et al. Discovery of a rich gene pool of bat SARSrelated coronaviruses provides new insights into the origin of SARS coronavirus. PLoS pathogens. 2017;13(11).

12. Yin Y, Wunderink RG. MERS, SARS and other coronaviruses as causes of pneumonia. Respirology. 2018;23(2):130-7.

13. Song $Z$, Xu Y, Bao L, Zhang L, Yu P, Qu Y, et al. From SARS to MERS, thrusting coronaviruses into the spotlight. Viruses. 2019;11(1):59.

14. html WHOJhwwicsctei. Summary of probable SARS cases with onset of illness from 1 November 2002 to 31 July 2003. 2003.

15. Lee N, Hui D, Wu A, Chan P, Cameron P, Joynt GM, et al. A major outbreak of severe acute respiratory syndrome in Hong Kong. New England Journal of Medicine. 2003;348(20):1986-94.

16. Assiri A, Al-Tawfiq JA, Al-Rabeeah AA, Al-Rabiah FA, Al-Hajjar S, Al-Barrak A, et al. Epidemiological, demographic, and clinical characteristics of 47 cases of Middle East respiratory syndrome coronavirus disease from Saudi Arabia: a descriptive study. The Lancet infectious diseases. 2013;13(9):752-61.

17. Moxley G, Posthuma D, Carlson P, Estrada E, Han J, Benson LL, et al. Sexual dimorphism in innate immunity. Arthritis \& Rheumatism. 2002;46(1):250-8.

18. Badawi A, Ryoo SG. Prevalence of comorbidities in the Middle East respiratory syndrome coronavirus (MERS-CoV): a systematic review and meta-analysis. International Journal of Infectious Diseases. 
2016;49:129-33.

19. Wu C, Chen X, Cai Y, Zhou X, Xu S, Huang H, et al. Risk factors associated with acute respiratory distress syndrome and death in patients with coronavirus disease 2019 pneumonia in Wuhan, China. JAMA internal medicine. 2020.

20. Zhou F, Yu T, Du R, Fan G, Liu Y, Liu Z, et al. Clinical course and risk factors for mortality of adult inpatients with COVID-19 in Wuhan, China: a retrospective cohort study. Lancet (London, England). 2020;395(10229):1054-62.

21. Ehsan allah K, Rajabi A. COVID-19 and digital epidemiology. Journal of Public Health. 2020:1.

\section{Tables}


Table 1

Baseline Characteristics of Patients Suspected and Infected With 2019-nCoV

\begin{tabular}{|c|c|c|c|c|c|}
\hline & $\begin{array}{l}\text { Total } \\
(n= \\
2,835)\end{array}$ & $\begin{array}{l}\text { Confirmed } \\
\text { cases } \\
(n=874)\end{array}$ & $\begin{array}{l}\text { Suspected } \\
\text { cases } \\
(n=1,046)\end{array}$ & $\begin{array}{l}\text { Not available of } \\
\text { PCR result } \\
(n=915)\end{array}$ & $P$ value \\
\hline Age, median (IQR), y & $\begin{array}{l}54(41- \\
67)\end{array}$ & $56(43-68)$ & $52(39-65)$ & $55(42-67)$ & $\begin{array}{l}< \\
0.001^{* *}\end{array}$ \\
\hline \multicolumn{6}{|l|}{ Sex, N (\%) } \\
\hline Female & $\begin{array}{l}1200 \\
(42.33)\end{array}$ & $\begin{array}{l}366 \\
(41.88)\end{array}$ & $\begin{array}{l}453 \\
(43.31)\end{array}$ & $381(41.64)$ & \multirow[t]{2}{*}{0.52} \\
\hline Male & $\begin{array}{l}1635 \\
(57.67)\end{array}$ & $\begin{array}{l}508 \\
(58.12 \%)\end{array}$ & $\begin{array}{l}593 \\
(56.69)\end{array}$ & $534(58.36)$ & \\
\hline \multicolumn{6}{|l|}{$\begin{array}{l}\text { Onset of symptom to, } \\
\text { median (IQR), d }\end{array}$} \\
\hline Hospital admission & $2(0-3)$ & $2(0-4)$ & $1(0-4)$ & $2(1-3)$ & 0.63 \\
\hline Death & $\begin{array}{l}7(4- \\
13)\end{array}$ & $8(4-13)$ & $8(3-14.5)$ & $6(3-8)$ & 0.86 \\
\hline Discharge & $\begin{array}{l}8(5- \\
12)\end{array}$ & $8(5-12)$ & $8(5-12)$ & $6(4-9)$ & 0.87 \\
\hline \multicolumn{6}{|c|}{$\begin{array}{l}\text { History of exposure with } \\
\text { COVID-19, } N(\%)\end{array}$} \\
\hline Yes & $\begin{array}{l}32 \\
(1.13)\end{array}$ & $11(1.26)$ & $21(2.01)$ & $0(0.0)$ & \multirow[t]{2}{*}{0.2} \\
\hline No & $\begin{array}{l}2803 \\
(98.87)\end{array}$ & $\begin{array}{l}863 \\
(98.74)\end{array}$ & $\begin{array}{l}1025 \\
(97.99)\end{array}$ & $915(100)$ & \\
\hline \multicolumn{6}{|l|}{ Ventilation, N (\%) } \\
\hline Yes & $\begin{array}{l}508 \\
(17.92)\end{array}$ & $\begin{array}{l}227 \\
(25.97)\end{array}$ & $\begin{array}{l}179 \\
(17.11)\end{array}$ & $102(11.15)$ & \multirow[t]{2}{*}{$0.72^{\star \star \star}$} \\
\hline No & $\begin{array}{l}289 \\
(10.19)\end{array}$ & $\begin{array}{l}105 \\
(12.01)\end{array}$ & $88(8.41)$ & 96 (10.49) & \\
\hline \multicolumn{6}{|l|}{ Admitted to ICU, N (\%) } \\
\hline Yes & $\begin{array}{l}340 \\
(11.99)\end{array}$ & $\begin{array}{l}105 \\
(12.01)\end{array}$ & $\begin{array}{l}127 \\
(12.14)\end{array}$ & $108(11.80)$ & \multirow[t]{2}{*}{$0.49^{\star \star \star}$} \\
\hline No & $\begin{array}{l}1153 \\
(40.67)\end{array}$ & $\begin{array}{l}377 \\
(43.14)\end{array}$ & $\begin{array}{l}412 \\
(39.39)\end{array}$ & 364 (39.78) & \\
\hline
\end{tabular}

**This test compared the Positive PCR group versus Negative PCR group. *** Some of the status variables are missing. 


\begin{tabular}{|c|c|c|c|c|c|}
\hline & $\begin{array}{l}\text { Total } \\
(n= \\
2,835)\end{array}$ & $\begin{array}{l}\text { Confirmed } \\
\text { cases } \\
(n=874)\end{array}$ & $\begin{array}{l}\text { Suspected } \\
\text { cases } \\
(n=1,046)\end{array}$ & $\begin{array}{l}\text { Not available of } \\
\text { PCR result } \\
(n=915)\end{array}$ & $P$ value \\
\hline \multicolumn{6}{|l|}{ SPO2, N (\%) } \\
\hline $93 \%>$ & $\begin{array}{l}411 \\
(14.50)\end{array}$ & $\begin{array}{l}168 \\
(19.22)\end{array}$ & $\begin{array}{l}150 \\
(14.34)\end{array}$ & $93(10.16)$ & \multirow[t]{2}{*}{$0.001^{\star \star \star}$} \\
\hline $93 \%<$ & $\begin{array}{l}408 \\
(14.39)\end{array}$ & $\begin{array}{l}119 \\
(13.62)\end{array}$ & $\begin{array}{l}179 \\
(17.11)\end{array}$ & $110(12.02)$ & \\
\hline Comorbidities, N (\%) & $\begin{array}{l}1012 \\
(35.70)\end{array}$ & $\begin{array}{l}356 \\
(40.73)\end{array}$ & $\begin{array}{l}335 \\
(32.03)\end{array}$ & $321(35.08)$ & $<0.001$ \\
\hline $\begin{array}{l}\text { Cardiovascular disease, } \mathrm{N} \\
(\%)\end{array}$ & $\begin{array}{l}486 \\
(17.14)\end{array}$ & $\begin{array}{l}168 \\
(19.22)\end{array}$ & $\begin{array}{l}160 \\
(15.30)\end{array}$ & $158(17.27)$ & 0.02 \\
\hline Diabetes, N (\%) & $\begin{array}{l}423 \\
(14.92)\end{array}$ & $\begin{array}{l}155 \\
(17.73)\end{array}$ & $\begin{array}{l}131 \\
(12.52)\end{array}$ & $137(14.97)$ & 0.001 \\
\hline Chronic lung disease, N (\%) & $\begin{array}{l}177 \\
(6.24)\end{array}$ & $65(7.44)$ & $71(6.79)$ & $41(4.48)$ & 0.58 \\
\hline Hypertension, N (\%) & $\begin{array}{l}77 \\
(2.72)\end{array}$ & $22(2.52)$ & $25(2.39)$ & $30(3.28)$ & 0.85 \\
\hline $\begin{array}{l}\text { Chronic kidney disease, N } \\
(\%)\end{array}$ & $\begin{array}{l}106 \\
(3.74)\end{array}$ & $46(5.26)$ & 39 (3.73) & $21(2.30)$ & 0.10 \\
\hline Chronic liver disease, N (\%) & $\begin{array}{l}21 \\
(0.74)\end{array}$ & $6(0.69)$ & $12(1.15)$ & $3(0.33)$ & 0.29 \\
\hline Cancer, N (\%) & $\begin{array}{l}44 \\
(1.55)\end{array}$ & $13(1.49)$ & $20(1.91)$ & $11(1.20)$ & 0.47 \\
\hline $\begin{array}{l}\text { Immune deficiency } \\
\text { disease, } N(\%)\end{array}$ & $\begin{array}{l}34 \\
(1.20)\end{array}$ & $5(0.57)$ & $15(1.43)$ & $14(1.53)$ & 0.06 \\
\hline \multicolumn{6}{|l|}{ Signs and symptoms } \\
\hline Respiratory distress, N (\%) & $\begin{array}{l}1795 \\
(63.32)\end{array}$ & $\begin{array}{l}565 \\
(64.65)\end{array}$ & $\begin{array}{l}692 \\
(66.16)\end{array}$ & $538(58.80)$ & 0.48 \\
\hline Fever, N (\%) & $\begin{array}{l}1601 \\
(56.47)\end{array}$ & $\begin{array}{l}495 \\
(56.64)\end{array}$ & $\begin{array}{l}599 \\
(57.27)\end{array}$ & $507(55.41)$ & 0.78 \\
\hline Dry cough, N (\%) & $\begin{array}{l}1595 \\
(56.26)\end{array}$ & $\begin{array}{l}478 \\
(54.69)\end{array}$ & $\begin{array}{l}575 \\
(54.97)\end{array}$ & $542(59.23)$ & 0.90 \\
\hline Sore throat, N (\%) & $\begin{array}{l}445 \\
(15.70)\end{array}$ & $\begin{array}{l}160 \\
(18.31)\end{array}$ & $\begin{array}{l}176 \\
(16.83)\end{array}$ & 109 (11.91) & 0.39 \\
\hline
\end{tabular}

**This test compared the Positive PCR group versus Negative PCR group. *** Some of the status variables are missing. 


\begin{tabular}{|c|c|c|c|c|c|}
\hline & $\begin{array}{l}\text { Total } \\
(n= \\
2,835)\end{array}$ & $\begin{array}{l}\text { Confirmed } \\
\text { cases } \\
(n=874)\end{array}$ & $\begin{array}{l}\text { Suspected } \\
\text { cases } \\
(n=1,046)\end{array}$ & $\begin{array}{l}\text { Not available of } \\
\text { PCR result } \\
(n=915)\end{array}$ & $P$ value \\
\hline Myalgia, N (\%) & $\begin{array}{l}342 \\
(12.06)\end{array}$ & $89(10.18)$ & $\begin{array}{l}155 \\
(14.82)\end{array}$ & $98(10.71)$ & 0.002 \\
\hline Headache, N (\%) & $\begin{array}{l}157 \\
(5.54)\end{array}$ & $43(4.92)$ & $36(3.93)$ & $78(7.46)$ & 0.02 \\
\hline Confusion, N (\%) & $\begin{array}{l}140 \\
(4.94)\end{array}$ & $39(4.46)$ & $62(5.93)$ & $39(4.26)$ & 0.15 \\
\hline $\begin{array}{l}\text { Nausea and Vomiting, N } \\
(\%)\end{array}$ & $\begin{array}{l}136 \\
(4.80)\end{array}$ & $45(5.15)$ & $59(5.64)$ & $32(3.50)$ & 0.63 \\
\hline Chest pain, $\mathrm{N}(\%)$ & $\begin{array}{l}112 \\
(3.95)\end{array}$ & 34 (3.89) & $48(4.59)$ & $30(3.28)$ & 0.45 \\
\hline Temperature, $\mathrm{C}$ & $\begin{array}{l}39(39- \\
39)\end{array}$ & $\begin{array}{l}39(38.5- \\
39)\end{array}$ & $39(39-39)$ & $39(39-39)$ & 0.07 \\
\hline \multicolumn{6}{|l|}{ Secondary end point } \\
\hline Death & $\begin{array}{l}563 \\
(19.86)\end{array}$ & $\begin{array}{l}288 \\
(32.95)\end{array}$ & $\begin{array}{l}190 \\
(18.16)\end{array}$ & $85(9.29)$ & \multirow[t]{3}{*}{$<0.001$} \\
\hline Recovered & $\begin{array}{l}1687 \\
(59.51)\end{array}$ & $\begin{array}{l}414 \\
(47.37)\end{array}$ & $\begin{array}{l}648 \\
(61.95)\end{array}$ & $625(68.31)$ & \\
\hline Hospitalization & $\begin{array}{l}585 \\
(20.63)\end{array}$ & $\begin{array}{l}172 \\
(19.68)\end{array}$ & $\begin{array}{l}208 \\
(19.89)\end{array}$ & $205(22.40)$ & \\
\hline
\end{tabular}


Table 2

Epidemiological and Clinical Characteristics among Death and Recovered Cases

\begin{tabular}{|c|c|c|c|c|}
\hline & $\begin{array}{l}\text { Death }(n= \\
\text { 288) }\end{array}$ & $\begin{array}{l}\text { Recovered }(n= \\
1687)\end{array}$ & $\begin{array}{l}\text { Total }(n= \\
\text { 1975) }\end{array}$ & $\begin{array}{l}P \\
\text { value }\end{array}$ \\
\hline Age, median (IQR), y & $65(54-76)$ & $50(39-62)$ & $53(41-65)$ & $\begin{array}{l}< \\
0.001\end{array}$ \\
\hline \multicolumn{5}{|l|}{ Sex, N (\%) } \\
\hline Female & $119(41.32)$ & $681(40.37)$ & $800(40.51)$ & \multirow[t]{2}{*}{0.76} \\
\hline Male & $169(58.68)$ & $1006(59.63)$ & $1175(59.49)$ & \\
\hline \multicolumn{5}{|c|}{$\begin{array}{l}\text { Onset of symptom to, median (IQR), } \\
d\end{array}$} \\
\hline Hospital admission & $1(0-4)$ & $2(1-4)$ & $2(0-4)$ & 0.32 \\
\hline Discharge & $4(2-10)$ & $7(4-11)$ & $7(4-11)$ & 0.44 \\
\hline \multicolumn{5}{|c|}{$\begin{array}{l}\text { History of exposure with COVID-19, } \\
N(\%)\end{array}$} \\
\hline Yes & $5(1.74)$ & $20(1.19)$ & $25(1.27)$ & \multirow[t]{2}{*}{0.44} \\
\hline No & $283(98.26)$ & $1667(98.81)$ & $1950(98.73)$ & \\
\hline \multicolumn{5}{|l|}{ Ventilation, $N(\%)$} \\
\hline Yes & 96 (76.19) & $235(57.18)$ & $331(61.64)$ & \multirow{2}{*}{$<.001$} \\
\hline No & $30(23.81)$ & $176(42.82)$ & $206(38.36)$ & \\
\hline \multicolumn{5}{|l|}{ Admitted to ICU, N (\%) } \\
\hline Yes & $36(22.22)$ & $197(22.70)$ & $233(22.62)$ & \multirow[t]{2}{*}{0.69} \\
\hline No & $126(77.78)$ & $671(77.30)$ & $797(77.38)$ & \\
\hline \multicolumn{5}{|l|}{ SPO2, N (\%) } \\
\hline $93 \%>$ & $191(66.32)$ & 1480 (87.73) & $1671(84.61)$ & \multirow{2}{*}{$\dot{0.001}$} \\
\hline $93 \%<$ & 97 (33.68) & $207(12.27)$ & 304 (15.39) & \\
\hline Comorbidities, N (\%) & $164(56.94)$ & $486(28.81)$ & $650(32.91)$ & $<0.001$ \\
\hline Cardiovascular disease, N (\%) & $80(27.78)$ & $223(13.22)$ & $303(15.34)$ & $<.001$ \\
\hline Diabetes, N (\%) & $68(23.61)$ & $219(12.98)$ & $287(14.53)$ & $<0.001$ \\
\hline Chronic lung disease, N (\%) & $34(11.81)$ & $79(4.68)$ & $113(5.72)$ & $\dot{0.001}$ \\
\hline
\end{tabular}




\begin{tabular}{|lllll|}
\hline & $\begin{array}{l}\text { Death }(\mathbf{n}= \\
\text { 288) }\end{array}$ & $\begin{array}{l}\text { Recovered }(\mathbf{n}= \\
\text { 1687) }\end{array}$ & $\begin{array}{l}\text { Total }(\mathbf{n}= \\
\text { 1975) }\end{array}$ & $\begin{array}{l}\text { v } \\
\text { value }\end{array}$ \\
\hline Hypertension, N (\%) & $13(4.51)$ & $39(2.31)$ & $52(2.63)$ & 0.03 \\
\hline Chronic kidney disease, N (\%) & $22(7.64)$ & $40(2.37)$ & $62(3.14)$ & 0.001 \\
\hline Chronic liver disease, N (\%) & $1(0.35)$ & $14(0.83)$ & $15(0.76)$ & 0.38 \\
\hline Cancer, N (\%) & $10(3.47)$ & $16(0.95)$ & $26(1.32)$ & 0.001 \\
\hline Immune deficiency disease, N (\%) & $2(0.69)$ & $14(0.83)$ & $16(0.81)$ & 0.81 \\
\hline Signs and symptoms & & & & \\
\hline Respiratory distress, N (\%) & $222(77.08)$ & $1006(59.63)$ & $1228(62.18)$ & 0.001 \\
\hline Fever, N (\%) & $162(56.25)$ & $1037(61.47)$ & $1199(60.71)$ & 0.09 \\
\hline Dry cough, N (\%) & $161(55.90)$ & $1041(61.71)$ & $1202(60.86)$ & 0.06 \\
\hline Sore throat, N (\%) & $49(17.01)$ & $284(16.83)$ & $333(16.86)$ & 0.94 \\
\hline Myalgia, N (\%) & $25(8.68)$ & $241(14.29)$ & $266(13.47)$ & 0.01 \\
\hline Headache, N (\%) & $9(3.13)$ & $120(7.11)$ & $129(6.53)$ & 0.01 \\
\hline Confusion, N (\%) & $11(3.82)$ & $80(4.74)$ & $91(4.61)$ & 0.49 \\
\hline Nausea and Vomiting, N (\%) & $11(3.82)$ & $94(5.57)$ & $105(5.32)$ & 0.22 \\
\hline Chest pain, N (\%) & $17(5.90)$ & $57(3.38)$ & $74(3.75)$ & 0.03 \\
\hline Temperature, C & $39(39-39)$ & $39(39-39)$ & $39(39-39)$ & 0.42 \\
\hline
\end{tabular}


Table 3

Multiple logistic regression analysis showing factors independently associated with death caused by 2019$\mathrm{nCoV}$

\begin{tabular}{|lll|}
\hline & AOR $^{*}$ (Cl 95\%) & P value \\
\hline Age & $1.03(1.02-1.04)$ & $<0.001$ \\
\hline SPo2 $<93 \%$ & $2.44(1.79-3.31)$ & $<0.001$ \\
\hline Comorbidities & $2.15(1.62-2.84)$ & $<0.001$ \\
\hline Respiratory distress & $1.74(1.28-2.37)$ & $<0.001$ \\
\hline Myalgia & $0.77(0.48-1.22)$ & 0.27 \\
\hline Headache & $0.44(0.21-0.92)$ & 0.03 \\
\hline *AOR: Adjusted Odds Ratio & \\
\hline
\end{tabular}

